\title{
DEVELOPMENT AND VALIDATION OF HIGH-PERFORMANCE THIN-LAYER CHROMATOGRAPHY METHOD FOR SIMULTANEOUS ESTIMATION OF NEBIVOLOL HYDROCHLORIDE AND CILNIDIPINE
}

\author{
MINAL R. GHANTE ${ }^{1 *}$, NATASHA AKHADE ${ }^{1}$, PREETI GOTA ${ }^{2}$, ATUL NIKAM ${ }^{1}$, SUPRIYA JAGTAP ${ }^{1}$, VANDANA NIKAM ${ }^{1}$ \\ ${ }^{1}$ Sinhgad Technical Education Society, Smt. Kashibai Navale College of Pharmacy, Pune. ${ }^{2}$ Gahlot Institute of Pharmacy, Koparkhaine, Navi \\ Mumbai. Email: mrghante@gmail.com
}

Received: 22 November 2018, Revised and Accepted: 18 Febraury 2018

ABSTRACT

Objective: The proposed method describes method development and validation of nebivolol hydrochloride and cilnidipine in combined pharmaceutical tablet dosage form by high-performance thin-layer chromatography (HPTLC) having adequate specificity, sensitivity, and reproducibility.

Methods: Nebivolol hydrochloride and cilnidipine drug combination is used for the treatment of hypertension. Precoated aluminum plates with silica gel $60 \mathrm{~F}_{254}$ (E-Merck, Germany) were used for the chromatographic separation which was carried using chloroform:glacial acetic acid:methanol, in 8.5:1:0.5 (v/v/v) as a mobile phase. HPTLC separation of two drugs was carried by densitometric measurement at $270 \mathrm{~nm}$.

Reults: The drugs were satisfactorily resolved with retardation factor values of $0.0 .29 \pm 0.008$ and $0.69 \pm 0.007$ for nebivolol hydrochloride and cilnidipine, respectively. The method was found to be linear in the range of 100-1000 ng/spot and 50-500 ng/spot for nebivolol hydrochloride and cilnidipine, respectively. The correlation coefficient was found to be 0.989 and 0.996 for nebivolol hydrochloride and cilnidipine, respectively. Limit of detection and limit of quantitation values were $16.395 \mathrm{ng} / \mathrm{band}$ and $49.681 \mathrm{ng} / \mathrm{band}$ and 31.788ng/band and $96.328 \mathrm{ng} / \mathrm{band}$, respectively. The mean recovery was found to be 100.570-101.936 and 100.269-101.333 for nebivolol hydrochloride and cilnidipine, respectively. The intra- and inter-day precision was found to be within the limit.

Conclusion: A simple, accurate, precise, and sensitive HPTLC method has been developed and validated in combined pharmaceutical tablet dosage form for simultaneous estimation of nebivolol hydrochloride and cilnidipine.

Keywords: Method development high-performance thin-layer chromatography, Nebivolol hydrochloride, Cilnidipine, International Council for Harmonisation.

(C) 2019 The Authors. Published by Innovare Academic Sciences Pvt Ltd. This is an open access article under the CC BY license (http://creativecommons. org/licenses/by/4. 0/) DOI: http://dx.doi.org/10.22159/ajpcr.2019.v12i4.30569

\section{INTRODUCTION}

Hypertension is a disease characterized by abnormal elevation of blood pressure (BP) in the arteries. It is broadly classified as primary and secondary. About $90-95 \%$ of cases are termed as primary (idiopathic) hypertension, which refers to high BP for which no exact cause can be found. The remaining $5-10 \%$ of secondary hypertension can be caused by conditions that affect your kidneys, arteries, heart or endocrine system. Prevention and control of high $\mathrm{BP}$ are the main focuses for reducing the severity of cardiovascular diseases [1].

Combination of drugs such as nebivolol $\mathrm{HCl}$ and cilnidipine has been prescribed to manage hypertension [2]. Nebivolol $\mathrm{HCl}$ (1RS, 1'RS)-1,1'-[(2RS,2'SR)-bis (6-fluo ro-3,4-dihydro- $2 \mathrm{H}-1$ benzopyran-2-yl)]- 2,2'-iminodiethanol hydrochloride [3] is a highly selective $\beta 1$-blocker with nitric oxide-mediated vasodilatory actions and beneficial effects on vascular endothelial function.

Cilnidipine is a dihydropyridine calcium channel blocker. It is a dual blocker of L-type voltage-gated calcium channels in vascular smooth muscle and $\mathrm{N}$-type calcium channels in sympathetic nerve terminals that supply blood vessels [4]. This combination is launched in the market under brand name Ln Beta, manufactured by Eris Lifesciences Pvt. Ltd., Ahmedabad.

It was found that UV spectroscopic, stability-indicating RP-HPLC, HPLC, and bioanalytical methods have been reported for analysis of these two drugs in combination [5-12]. However, there is only one paper reported for the analysis of the combination by high-performance thin-layer chromatography (HPTLC) [13].

In view of the need for a suitable method for routine analysis in combined formulations, attempts are being made to develop simple, precise, accurate, rapid, economical, and reproducible analytical methods for the simultaneous estimation of nebivolol $\mathrm{HCl}$ and cilnidipine and extend it to their determination in the formulation. The work deals with development and validation of HPTLC method for the estimation of nebivolol $\mathrm{HCl}$ and cilnidipine by HPTLC in accordance with the International Council for Harmonisation (ICH) guidelines for analytical application.

Nebivolol hydrochloride and cilnidipine were a generous gift by Actavis Pharmaceuticals Ltd., Mumbai, India and Prayosha Healthcare Pvt. Ltd., Ankleshwar, India, respectively. Chloroform, glacial acetic acid, methanol, and all other chemicals used were of analytical reagent grade.

\section{Equipment}

The instruments used in the study were Camag HPTLC system comprising Linomat-5 applicator, Camag thin-layer chromatography scanner 3, Win Computer-Aided Transcription System software (Version 1.4.3, Camag), aluminum plates precoated with silica gel $60 \mathrm{~F}_{254}$ (E-Merck, Germany), Hamilton syringe $(100 \mu \mathrm{l})$, and Deuterium lamp which was used as a radiation source. Shimadzu balance model AY-120, hot air oven (Kumar Laboratory Oven), photostability chamber (Make Newtronic. Model IC DAC version 1.2), and calibrated glass wares were used for the study. 
HPTLC analysis

Standard solution preparation and selection of analytical wavelength

Stock solution for cilnidipine and nebivolol hydrochloride was prepared by dissolving $10 \mathrm{mg}$ of drug in $10 \mathrm{ml}$ methanol. Further dilution of nebivolol hydrochloride and cilnidipine stock solution was made using methanol to get the standard solution having $100 \mu \mathrm{g} / \mathrm{mL}$ and $50 \mu \mathrm{g} / \mathrm{mL}$, respectively.

From the standard stock solution, further dilutions were done using methanol and scanned over the range of 200-400 nm, and the spectra were obtained. It was observed that both drugs showed considerable absorbance at $270 \mathrm{~nm}$.

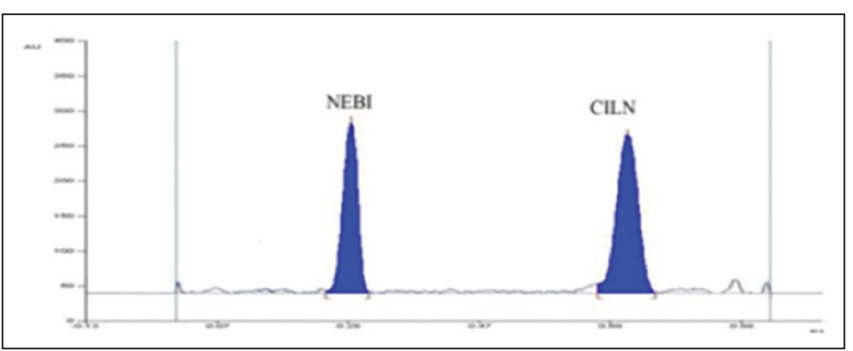

Fig. 1: Densitogram of nebivolol $\mathrm{HCl}(100 \mathrm{ng} / \mathrm{band})$ and cilnidipine (200 $\mathrm{ng} / \mathrm{band})$

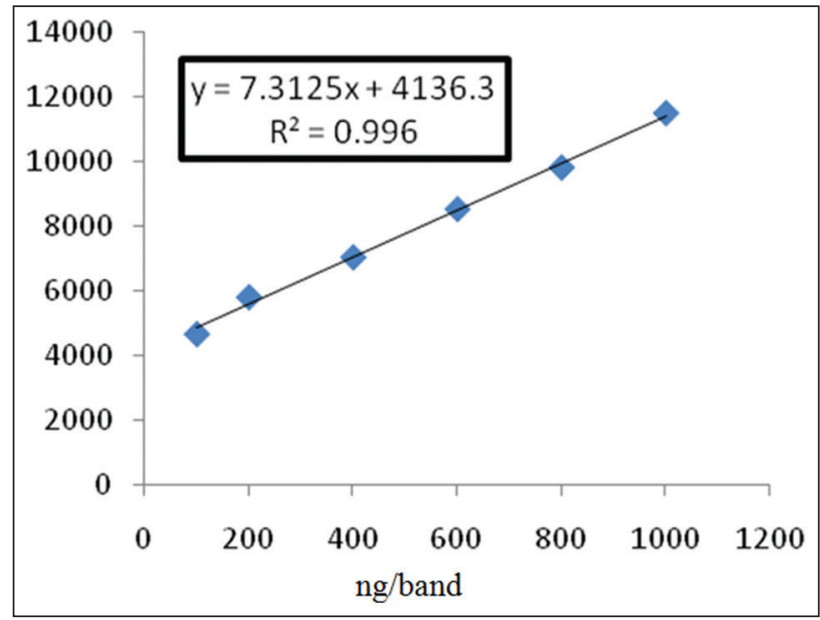

Fig 2: Calibration curve for nebivolol $\mathrm{HCl}$

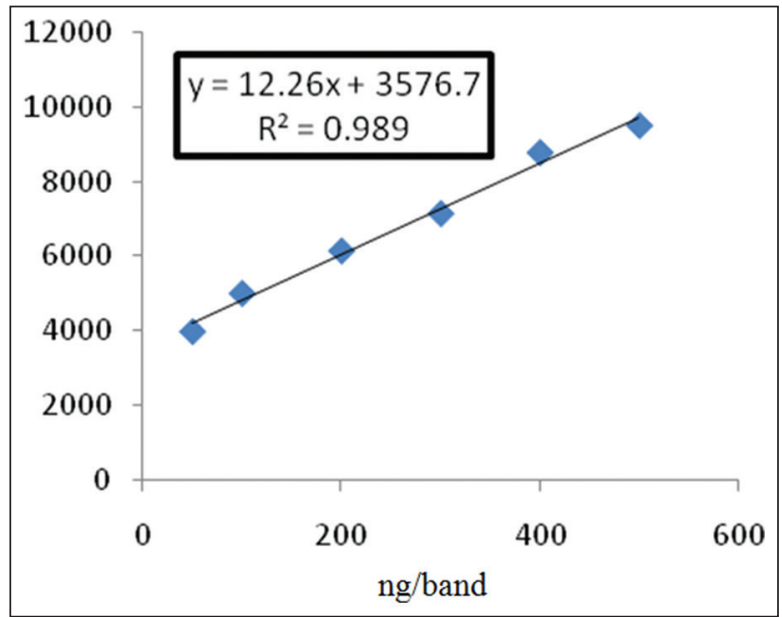

Fig 3: Calibration curve for cilnidipine
Chromatographic conditions

Samples were applied on the $10 \mathrm{~cm} \times 10 \mathrm{~cm}$ plate as a band with a width of $6 \mathrm{~mm}$ and slit dimensions were kept as $4.00 \times 0.45 \mathrm{~mm}$. Chamber saturation time was $20 \mathrm{~min}$ and the migration distance was $80 \mathrm{~mm}$. Mobile phase used was chloroform:glacial acetic acid:methanol, in 8.5:1:0.5 (v/v/v) ratio.

\section{Analysis of tablet formulation}

Twenty tablets were weighed accurately and finely powdered. A quantity of powder equivalent to $10 \mathrm{mg}$ of cilnidipine $(5 \mathrm{mg}$ of Nebivolol hydrochloride) was weighed and transferred to a $10 \mathrm{ml}$ volumetric flask containing about $5 \mathrm{ml}$ of methanol and shaken for $5 \mathrm{~min}$, and volume was made up with the methanol. The solution was filtered using Whatman paper No. 41, and $1 \mathrm{ml}$ filtrate was further diluted to $10 \mathrm{ml}$ with methanol to get sample stock solution of $100 \mathrm{ng} / \mu \mathrm{l}$ of cilnidipine and $50 \mathrm{ng} / \mu \mathrm{l}$ of nebivolol hydrochlordie. $2 \mathrm{ml}$ of sample solution was applied on HPTLC plate to obtain a final concentration of $200 \mathrm{ng} / \mathrm{band}$ of cilnidipine and $100 \mathrm{ng} / \mathrm{band}$ of nebivolol. After chromatographic development, peak areas of the bands were measured at $270 \mathrm{~nm}$ and concentration of drug in the sample was estimated from the calibration curves. Procedure was repeated 6 times for the analysis of homogenous sample.

\section{METHOD VALIDATION [14]}

The method was validated as per the ICH guidelines.

\section{Linearity}

The standard stock solution of cilnidipine $(100 \mathrm{ng} / \mu \mathrm{l})$ and nebivolol hydrochloride $(50 \mathrm{ng} / \mu \mathrm{l})$ was applied as over spotting on HPTLC plate

Table 1: Calibration curve of nevibolol hydrochloride and cilnidipine $(n=6)$

\begin{tabular}{llllll}
\hline \multirow{2}{*}{$\begin{array}{l}\text { Sr. } \\
\text { No }\end{array}$} & \multicolumn{2}{c}{ Nebivolol hydrochloride } & & \multicolumn{2}{c}{ Cilnidipine } \\
\cline { 2 - 3 } \cline { 5 - 6 } & $\begin{array}{l}\text { Concentration } \\
\text { (ng/band) }\end{array}$ & $\begin{array}{l}\text { Peak } \\
\text { area }\end{array}$ & & $\begin{array}{l}\text { Concentration } \\
\text { (ng/band) }\end{array}$ & $\begin{array}{l}\text { Peak } \\
\text { area }\end{array}$ \\
\hline 1 & 100 & 4686 & & 50 & 3955.4 \\
2 & 200 & 5825.4 & & 100 & 4981.6 \\
3 & 400 & 7061 & & 200 & 7132.4 \\
4 & 600 & 8553.1 & & 300 & 8770.6 \\
5 & 800 & 9839.8 & & 400 & 9496.6 \\
6 & 1000 & 11521.5 & 500 & \\
\hline
\end{tabular}

Table 2: Regression analysis of calibration curves of nebivolol $\mathrm{HCl}$ and cilnidipine

\begin{tabular}{lll}
\hline Parameter & Cilnidipine & Nebivolol HCl \\
\hline Detection Wavelength (nm) & 270 & 270 \\
Linearity range (ng/band) & $100-1000$ & $50-500$ \\
Correlation coefficient (r) & 0.996 & 0.989 \\
Linear regression equation & & \\
(y=mx+c) & & \\
$\quad$ Intercept (c) & 4136.3 & 3576.7 \\
$\quad$ Slope (m) & 7.312 & 12.26 \\
\hline HCl: Hydrochloride & &
\end{tabular}

Table 3: Statistical validation of intra- and inter-day precision studies

\begin{tabular}{lllll}
\hline Component & Precision & $\begin{array}{l}\text { \% of Label } \\
\text { claim }\end{array}$ & SD & \% RSD \\
\hline Cilnidipine & Intraday $(n=6)$ & 101.128 & 0.961 & 0.009 \\
& Interday $(\mathrm{n}=3 \times 3)$ & 100.003 & 1.115 & 0.011 \\
Nebivolol & Intraday $(\mathrm{n}=6)$ & 101.260 & 1.517 & 0.014 \\
HCl & Interday $(\mathrm{n}=3 \times 3)$ & 100.675 & 1.046 & 0.010 \\
\hline
\end{tabular}


Table 4: Recovery studies of nebivolol $\mathrm{HCl}$ and cilnidipine $(\mathrm{n}=3)$

\begin{tabular}{llllll}
\hline Drug & Amount taken (ng per band) & Amount added (ng/band) & Total amount (ng/band) & \% Recovery* & \% RSD* \\
\hline Nebivolol & 100 & 50 & 150 & 100.696 & 1.396 \\
hydrochloride & 100 & 100 & 200 & 101.936 & 1.137 \\
& 100 & 150 & 250 & 100.570 & 1.744 \\
Cilnidipine & 200 & 100 & 300 & 100.269 & 0.869 \\
& 200 & 200 & 400 & 101.333 & 1.685 \\
& 200 & 300 & 500 & 100.849 & 1.445 \\
\hline
\end{tabular}

RSD: Reflex sympathetic dystrophy, HCl: Hydrochloride

Table 5: LOD and LOQ

\begin{tabular}{lll}
\hline Parameters & Nebivolol hydrochloride & Cilnidipine \\
\hline LOD (ng/band) & 16.395 & 31.788 \\
LOQ (ng/band) & 49.681 & 96.328 \\
\hline LOD: Limit of Detection LOQ: Limit of Quantitiation
\end{tabular}

Table 6: Robustness data in terms of \% RSD $(n=3)$

\begin{tabular}{|c|c|c|c|c|}
\hline $\begin{array}{l}\text { Sr. } \\
\text { No }\end{array}$ & Parameters & Variation & $\begin{array}{l}\% \text { RSD}^{*} \\
\text { NEB }\end{array}$ & $\begin{array}{l}\text { \% RSD* } \\
\text { CIL }\end{array}$ \\
\hline 1 & $\begin{array}{l}\text { Time from application } \\
\text { to development }\end{array}$ & $\begin{array}{l}0,30 \text {, and } \\
60 \mathrm{~min}\end{array}$ & 0.099 & 0.054 \\
\hline 2 & $\begin{array}{l}\text { Time from development } \\
\text { to scanning }\end{array}$ & $\begin{array}{l}0,30 \text {, and } \\
60 \text { min }\end{array}$ & 0.057 & 0.028 \\
\hline
\end{tabular}

RSD: Reflex sympathetic dystrophy

Table 7: Analysis of tablet formulation by HPTLC

\begin{tabular}{lllll}
\hline Drug & $\begin{array}{l}\text { Label claim } \\
\text { (mg/tablet) }\end{array}$ & $\begin{array}{l}\text { \% of label } \\
\text { claim }\end{array}$ & SD* $^{*}$ & $\begin{array}{l}\text { \% } \\
\text { RSD* }\end{array}$ \\
\hline $\begin{array}{l}\text { Cilnidipine } \\
\text { Nebivolol }\end{array}$ & 10 & 101.417 & 1.799 & 0.017 \\
hydrochloride & 5 & 100.955 & 1.565 & 0.015 \\
\hline
\end{tabular}

*Average of six determinations. HPTLC: High-performance thin-layer

chromatography, RSD: Reflex sympathetic dystrophy

in range of $1-10 \mu \mathrm{l}$ with the help of CAMAG $100 \mu \mathrm{L}$ sample syringe, using Linomat 5 sample applicator to obtain final concentration 100-1000 ng/band for cilnidipine and 50-500 ng/band for nebivolol hydrochlordie. The plate was developed and scanned under the above established chromatographic conditions. Each standard in six replicates was analyzed, and peak areas were recorded. Calibration curves of cilnidipine and nebivolol hydrochloride were plotted of peak area versus concentration.

\section{Intra- and inter-day precision}

The precision of the method was demonstrated by intra- and inter-day variation studies. In the intraday studies, six replicates of standard solution $(200 \mathrm{ng} /$ band for cilnidipine and $100 \mathrm{ng} /$ band for nebivolol hydrochloride - Assay Concentration) were analyzed in a day and percentage reflex sympathetic dystrophy (RSD) was calculated. For the interday variation studies, three replicates of standard solutions $(200$, 400 , and $600 \mathrm{ng} / \mathrm{band}$ for cilnidipine and 100, 200, and $300 \mathrm{ng} / \mathrm{band}$ for nebivolol) were analyzed on 3 consecutive days and percentage RSD was calculated.

\section{Accuracy}

To check the accuracy of the method, recovery studies were carried out by over spotting standard drug solution to pre-analyzed sample solution at three different levels of 50,100 , and $150 \%$. The basic concentration of sample chosen was $200 \mathrm{ng} / \mathrm{band}$ for cilnidipine and $100 \mathrm{ng} / \mathrm{band}$ for nebivolol hydrochloride. The areas were noted after the development of plate. The drug concentration was calculated using regression equations.

\section{Limit of detection (LOD)}

LOD was calculated from the following formula:

$\mathrm{LOD}=3.3 \sigma / \mathrm{S}$

Where

$\sigma=$ Standard deviation of the response (y-intercept)

$\mathrm{S}=$ Slope of the calibration curve

Limit of quantitation (LOQ)

LOQ was calculated from the following formula:

$\mathrm{LOQ}=10 \sigma / \mathrm{S}$

Where

$\sigma=$ Standard deviation of the response (y-intercept)

$\mathrm{S}=$ Slope of the calibration curve

\section{Robustness}

The robustness of the method was studied, during method development, by small but deliberate variations in time from application to development $(0,30$, and $60 \mathrm{~min})$ and time from development to scanning $(0,30$, and 60$)$. One factor at a time was changed at a concentration level of $200 \mathrm{ng} /$ band for cilnidipine and $100 \mathrm{ng} /$ band for nebivolol hydrochloride to study the effect on the peak area of the drugs.

\section{RESULTS AND DISCUSSION}

The standard densitograms of nebivolol hydrochloride and cilnidipine are shown in Fig. 1.

Nebivolol retardation factor $(\mathrm{Rf})=0.29 \pm 0.008$

Cilnidipine $\mathrm{Rf}=0.69 \pm 0.007$

\section{Linearity}

The linearity data for calibration curve is shown in Table 1 , the calibration curve for nebivolol hydrochloride and cilnidipine is shown in Figs. 2 and 3, respectively, and the regression data are shown in Table 2.

The results for precision studies and accuracy are shown in Tables 3 and 4.The results for LOD and LOQ for nebivolol hydrochloride and cilnidipine are shown in Table 5.The robustness data are shown in Table 6.

\section{Analysis of tablet formulation}

After chromatographic development, peak areas of the bands were measured at $270 \mathrm{~nm}$ and concentration of drug in the sample was estimated from the calibration curves. The procedure was repeated 6 times for the analysis of homogenous sample. The results for tablet analysis are shown in Table 7.

\section{DISCUSSION}

HPTLC method for the determination of nebivolol hydrochloride and cilnidipine was developed. Linearity for nebivolol hydrochloride and cilnidipine was found in the range of 100-1000 ng/band and $50-500 \mathrm{ng} /$ band and regression coefficient $\left(\mathrm{r}^{2}\right)=0.989$ and 0.986 , 
respectively. It indicates that the proposed method found to be linear. LOD and LOQ values were $16.395 \mathrm{ng} /$ band and $49.681 \mathrm{ng} / \mathrm{band}$ and $49.681 \mathrm{ng} /$ band and $96.328 \mathrm{ng} /$ band, respectively, and this low value of LOD and LOQ indicates that the proposed method is sensitive. The RSD values for intra- and inter-day precision studies were found to be $<2 \%$; this low value of RSD indicates that the proposed method is precise.

\section{CONCLUSION}

A new, simple, and sensitive HPTLC method has been successfully developed and validated for simultaneous determination of nebivolol hydrochloride and cilnidipine in bulk and pharmaceutical dosage form. The method was found to be accurate, precise, and economic and hence can be used for routine analysis of the drugs in combination.

\section{AUTHOR'S CONTRIBUTION}

Authors declare that this study was performed by all mentioned in this article. All liabilities relating to claims of the contents of this article will be borne by the authors.

\section{CONFLICTS OF INTEREST}

The are no conflicts of interest by the authors regarding the publication of this.

\section{REFERENCES}

1. Fuchs FD. Essential of Hypertension. New york: Springer; 2017.

2. Available from: https://www.1mg.com/generics/nebivolol- cilnidipine -402479. [Last accessed on 2018 Nov 20].

3. Indian Pharmacopoeial Commission. Indian Pharmacopoeia. Ghaziabad: Ministry of Health and Family Welfare Government of India; 2014. p. 2310-2

4. Godfraind T. Discovery and development of calcium channel blockers. Front Pharmacol 2017;8:286

5. Patel BD. Development and validation of reversed phase high performance liquid chromatography method for simultaneous estimation of nebivolol $\mathrm{HCl}$ and cilnidipine in combined tablet dosage form. Pharm Biol Eval 2016;3 Suppl 2:208-14

6. Patel PR, Patel N, Shah SK. Analytical method development and validation for simultaneous estimation of nebivolol hydrochloride and cilnidipine in combined dosage form. J Chem Pharm Res 2015;7:951-60.

7. Aruna G, Bharathi K, Prasad KV. Development and validation of bioanalytical HPLC method for simultaneous estimation of cilnidipine and nebivolol in human plasma. Int J Pharm Pharm Sci 2017;9 Suppl 10:253-9.

8. Thula KC, Patel DM, Maheshwari DG. Development and validation of first order derivative UV spectrophotometric method for simultaneous estimation of nebivolol and cilnidipine in pharmaceutical formulation. Int J Pharm Sci Rev Res 2015;31 Suppl 1:243-7.

9. Patel PR, Patel N, Shah SK. Analytical method development and validation for simultaneous estimation of nebivolol hydrochloride and cilnidipine in combined dosage form. J Chem Pharm Res 2015;7:951-60.

10. Patel ND, Mehta1 RS, Captain AD, Karkhanis VV, Patel PD, Chavda AA. Development and validation of stability indicating RP-HPLC method for simultaneous estimation of nebivolol hydrochloride and cilnidipine in tablet dosage form. J Pharm Sci Biosci Res 2017;7 Suppl 1:140-7.

11. Kumbhar ST, Chougule GK, Tegeli VS, Gajeli GB, Thorat YS, Shivsharan US. A validated HPTLC method for simultaneous quantification of nebivolol and hydrochlorothiazide in bulk and tablet formulation. Int J Pharm Sci Drug Res 2011;3 Suppl 1:62-6.

12. Kokilambigai KS, Lakshmi KS, Kumar A, Chandrayan G, Satyam K, Singh MK. Spectrophotometric estimation of cilnidipine in bulk and pharmaceutical dosage form using $\mathrm{N}-(1-\mathrm{Naphthyl})$ ethylene diamine dihydrochloride. Int J Pharm Pharm Sci 2014;6 Suppl 9:576-8.

13. Shah DM, Doshi DB. Development and validation of HPTLC method for simultaneous estimation of nebivolol hydrochloride and cilnidipine in combined pharmaceutical tablet dosage form. Int J Pharma Res Rev 2016;5 Suppl 6:1-7.

14. ICH Harmonized Tripartite Guideline Validation of Analytical Procedures: Text and Methodology, Q2 (R1); 2005. p. 1-28. 